1873.] MEETING OF THE PIONEERS OF POLK COUNTY.

\title{
ANNUAL MEETING OF THE PIONEERS OF POLK OOUNTY.
}

$\bigcap^{N}$ the 30th of last August the old settlers of Polk county held their thirteenth annual gathering. We copy from the State Register:-

"The annual gathering of old settlers of Polk county yesterday was more numerously attended than any that had preceded it. Over six hundred sat down to dinner, which was one of the best ever served in the eity. The audience collected at the grounds about ten o'clock, and were called to order by President Thomas Mitrhell. Rev. Mr. Wright made the opening prayer, which was followed by the singing of the Old Settlers' 'Auld Lang Syne.' Then followed the narration of incidents of early life in Iowa. Among others, Mr. Isaac Cooper and Mr. Philo L. Case presented curiosities of the early day - the former the chair and table described in yesterday's Register, and the latter the first ballot-box that was used in Four-Mile township. All the incidents were full of interest and were heartily applauded. While the story-telling was going on among the old folks, the vounger members of the organization were tripping away the hours in Mechanic's Hall to the music of Mechanic's brass band.

"After dinner the toasts were announced and responded to according to published programme, with the exception of the one assigned to Hon. D. O. Finch. That gentleman being ill, Judge Wright took his place, and spoke eloquently for 'the future Pittsburg.' Hon. Curtis Bates was extremely happy in his comparison of the days of 1846 and 1873. He was full of reminiscence, and entertaining in the extreme. Dr.'Shaw spoke learnedly and well for the agricultural and industrial interests of the state.

"Hoyt Sherman, jr., ' the boy of '46 and man of '73,' was apt.

"At the conclusion of the speech-making, Hon. Thomas 
Mitchell was re-elected president, and R. L. Tidrick, Esq., secretary, for the ensuing year and the formal exercises of the day were closed with prayer by Rev. Mr.'Nash.

"Then came a dance in the hall, in which some of the gray-beards grew young, and so with feast and song and dance closed the thirteenth annual reunion of the Old Settlers of Polk county.

"Annexed will be found a resume of the county's history, written several years since by a gentleman who was among the most honored participants in the gathering:-

" "The county of Polk was included in the purchases made by the commissioners of the United States of the Sac and Fox Indians, at Agency City, October 11, 1842. The eastern portion of Iowa had been acquired by the previous treaties of 1832,1836 , and 1837 , but the aborigines yet remained, clinging tenaciously to their ancestral domain. When the western part of the territory was purchased from them, they were allowed to remain upon the lands ceded, and to have exclusive possession of them for the term of three years from the date of the treaty. They immediately removed from the Mississippi to the interior of the state, on the new purchases, where they were safe, for a time, from the intrusion of the whites, and could find the wilds and solitudes harmonions with their natures.

" "The Indian title to the lands of this portion of Iowa expired at midnight of October 11,1845 . This period was impatiently awaited by those already here, for after that time each was at liberty to make a claim of three hundred and twenty acres, which could be held until government brought the lands into market, and then purchased under such regulations as are now in force. Long before the expiration of the Indian title, the settlers around the fort had made arrangements with each other, and the most valuable tracts were already considered claims. Some claims were even measured and staked off, but this was of no validity, and done only for convenience, or to facilitate such subsequent survey as was absolutely necessary to establish and 
identify it. So eager were the settlers, who had previously remained only at the suffrance of the general government, to have permanaut homes near the fort, that during the fore part of the night preceding October 11th men were stationed in all directions around, with instructions to imme. diately begin the measurement of claims as soon as midnight arrived.

"“ Precisely at twelve o'clock, the loud report of a musket fired from the agency house announced that the empire of the red man ended here forever, and that of his master race begun. Answering reports rang sharply on the night air, in quick succession from every hill-top, and in every valley, till the signal was conveyed for miles around, and all understood that civilization had now commenced her reign in central Iowa. The moon was slowly sinking in the west, and its beams afforded a feeble and uncertain light for the measuring of claims, in which so many were engaged. Ere long the landscape was shrouded in darkness, save the wild and fitful glaring of torches carried by the claim-makers. Before the night had entirely worn away, the rough surveys were finished, and the Indian lands had found new tenants. Throughout the country thousands of acres were laid off in claims before dawn. Settlers rushed in by hundreds, and the region lately so tranquil and silent felt the impulse of the change, and became vocal with the sounds of industry and enterprise." "'

\section{A MOOTED POINT IN BLAOK AND WHITE.}

Council Blufrs, Iowa, July 28, 1873.

To the Secretary of the Historical Society of Lowa :-

DEAR SIR:- Enclosed please find a document which may be of some interest to the readers of your transactions. You will see from it that it is a proposition to raise 
Copyright of Annals of Iowa is the property of State of Iowa, by \& through the State Historical Society of Iowa and its content may not be copied or emailed to multiple sites or posted to a listserv without the copyright holder's express written permission. However, users may print, download, or email articles for individual use. 